Global Journal of Business and Social Science Review

Journal homepage: http://gatrenterprise.com/GATRJournals/index.html

\title{
Financing Sustainable Development: The Role of the European Union
}

\author{
Sanja Franc1* and Vlatka Bilas ${ }^{2}$ \\ ${ }^{1,2}$ Faculty of Economics and Business, University of Zagreb, 10000 Zagreb, Croatia
}

\begin{abstract}
Objective - Sustainable development is a multidimensional concept and therefore requires a varied, nonetheless integrative approach to decision making, creation of policies and fundraising. The aim of this paper is to bring about the main sources of financing sustainable development, as well as to analyze the role of the European Union in supporting global sustainable development goals. Although the EU has welcomed the new global development agenda, and has an important role as a leading global donor of development aid, in order to meet miscellaneous expectations for development effectiveness, within the region and globally, it will need to further its efforts and make more concrete actions and changes towards the path of sustainability.
\end{abstract}

Methodology/Technique - In investigating possible implication for financing sustainable development, authors refer to previous studies and EU reports.

Findings - The findings presented implications that need to be done in order to achieve Sustainable Development Goals. Foremost, it depends on successful development of national policies, their synergy and coherence. Public and private, domestic and international sources have an important role in financing development. While a certain level of government involvement is needed in terms of its strategic role and ensuring appropriate public funds, the existence of a healthy and stable economic and political system in the country is more important for attracting private investors.

Novelty - The study provides clear implications to finance sustainable development and role of EU in this.

Type of Paper: Review

Keywords: Sustainable Development, European Union, Financing Funds.

JEL Classification: G30, Q01, Q56.

\section{Introduction}

The United Nations Conference on Human Environment held in 1972 in Stockholm was a milestone for raising sustainable development awareness, when the international community for the first time jointly addressed the issue of global environment and development needs. Since then, several key documents were created concerning global sustainable development, namely the "Bruntland report" from 1989, the "Agenda 21" adopted in 1992, the "Millennium Declaration" from 2000 and others.

The framework for sustainable development for the period after 2015 is determined by the new " 2030 Agenda" that defined Sustainable Development Goals (SDGs) which are the latest universal set of goals, targets and

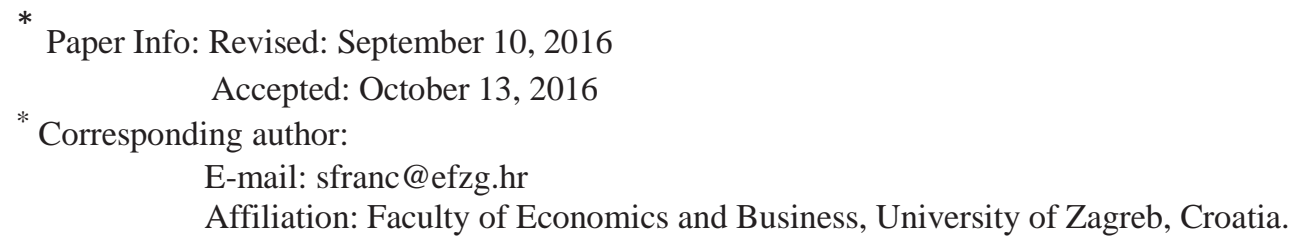


indicators that United Nations (UN) member states will be expected to use to frame their agendas and political policies over the next 15 years. Thus, the Millennium Development Goals (MDGs) set in the Millennium Declaration, which were supposed to be met by 2015, as of September 2015 obtained their successor in the Sustainable Development Goals. SDGs represent 17 goals adopted and designed in a way to eradicate poverty and hunger by 2030. While the MDGs focused on developing countries, the 2030 Agenda is the first global agreement in the history establishing a universal, comprehensive program of action intended to affect all countries and their national policies.

Sustainable development is a multidimensional concept and therefore requires a complex, nonetheless integrative approach to decision making, creation of policies and fundraising. The aim of this paper is to bring about the main sources of financing the sustainable development, as well as to analyze the role of the European Union, as one of the largest global development aid donors, in supporting sustainable development goals in partner economies.

\section{The Sustainable Development Goals and sources of financing}

The Sustainable Development Goals are intended to encourage the public and private sector, international organizations, non-governmental organizations and others on the achievement of specific, but different goals ranging from reducing poverty, strengthening food security, ensuring health, education to the preservation of biodiversity, prevention of climate change, etc. by 2030 (UNCTAD, 2014).

One of the main hurdles in achieving sustainable development goals is finding adequate financing sources. In other words, the challenges of financing sustainable development include (UNCTAD, 2014):

- Finding adequate funds for sustainable development, including finding funds on the financial markets or through financial intermediaries,

- Directing funds towards achieving the goals of sustainable development, which implies that these funds will be channeled into specific projects and in specific countries,

- Maximizing the positive impacts and minimize the negative ones, which implies the creation of a favorable environment and the establishment of investment protection when necessary involvement of the private sector.

Innovations in the design of new financial instruments, transmission mechanisms, institutional structures, etc., are being developed for centuries. Over time they achieved a number of improvements in the structures and processes of financial intermediation (Verghese, 1990). However, these improvements were modest as opposed to those that occurred in recent decades. The interconnectedness of companies and markets influenced the emergence of cross-border financing and financial liberalization process (Pirteä and associates, 2008).

As a financing source, the role of the public sector is crucial. But at the same time, the contribution of the private sector is also essential and irreplaceable in financing development (UNCTAD, 2014).

Public and private financing funds can be either domestic or international. Domestic public financing sources call for tax reform and deeper international cooperation. However, domestic efforts need to be complemented by international cooperation to address tax evasion and illicit flows. In the realm of private financing sources, a wide range of financial institutions should play a role, from microfinance, postal, cooperative and development banks in the traditional banking system. International public finance, including aid, climate finance, and other types of assistance, will remain central in financing sustainable development. Nevertheless, international private investments are also gaining importance (UN, 2014).

As a form of financial innovation, there are so-called "green bonds" that are primarily intended for investors inclined to combine social objectives and environmental objectives with profit making. Such bonds offer investors a safe return on the investment (since multilateral banks or donors usually guarantee for them). Earnings are often transferred to special accounts of which then financed loans for specific projects related to sustainable development. 
In recent years, the trend of increased private sector involvement in sectors such as water supply, telecommunications and transport, which are related to sustainable development, is recorded in developing countries. As the growing involvement of the private sector in the areas of economic infrastructure can be expected, more investments in the areas of social infrastructure (such as education) are not as probable. Thus, it can be said that the private investments for achieving the goals of sustainable development are necessary, but it should be noticed that there are also certain challenges and risks that those bring (UNCTAD, 2014).

It is important to notice that although there is increasing cooperation between the private and the public sector, they are not substitutes but rather complements. The private sector cannot and must not replace the public sector. The role of the public sector is larger than just securing the finance; the public sector is responsible for providing the conditions necessary for sustainable development. Furthermore, the involvement of private investors in areas of public interest, such as health, water and the like, is a sensitive issue because it can have a negative impact on the standards of these services. Also, although the goals of sustainable development are global, every country, and especially poorly developed countries have specific needs, which require the development of specific policies without which it will not be possible to attract private investors. Private investors should be understood as full partners in meeting the goals of sustainable development (Chandrasekhar, 2015). However, recognizing the private sector as a partner in development means that its contribution, and success should be assessed not only in terms of volume of activity, efficiency and profits, but in terms of the impact of its activities on equitable and sustainable development.

There are many reasons why the private sector has had a marginal role in supporting sustainable development so far (Chandrasekhar, 2015). First, levels and patterns of private investment were driven by the short or mediumterm considerations of profitability, with little attention given to long-term sustainability and development goals. Second, the efficiency of the private sector is to a large extent attributed to the maintenance of competitiveness and rivalry. This means that even if individual companies or managers seek to achieve goals other than profits, they may falter due to the competitive struggle in which they are forced to reconcile with those who seek to achieve the lowest short-term cost, despite adverse implications for development or sustainability. The above features have further increased in recent decades due to more liberal, market-oriented development strategies that have intensified the rivalry, competition and deregulation.

Sustainable development and attracting private investments both depend on the successful creation of national policies, their synergy and coherence. Incentives for foreign direct investments include providing measurable benefits to certain companies or categories of companies by the government of a potential recipient country to encourage certain kinds of behavior (Moran, 1998).

It is a known fact that investment policy is created depending on the political and economic environment, which has in recent years been affected by the global crisis. It can be said to have occurred fundamental changes in the investment environment and policies. The new generation of investment policies are marked by (UNCTAD, 2015): (1) the knowledge that investments are a key driver of growth and development and that investments are a central part of development strategies, (2) efforts to encourage the sustainable development with responsible investment, while also stressing the importance of economic growth and preservation of the environment and society, (3) attempts to solve problems that impair the effectiveness of investment policies and increase investment risk.

Through foreign investments multinational companies can significantly affect the well-being of a recipient country. The extent of this impact largely depends on the purpose and value of the investment, but also on laws and policies of the recipient country and concluded international investment agreements. However, while multinational companies, i.e. investors are interested in a limited number of private economic objectives, governments are interested in the realization of much broader economic and non-economic objectives. Multinational companies are trying to achieve an increase in profits and sales, while countries seek to achieve an increase in well-being of their citizens (Dunning, 1993). In this sense, there is no uniform consensus on the impact of foreign direct investment. Moreover, it can have very different effects in different countries (Chudnovsky and Lopez, 2008). 
As for the effects on the environment, foreign investments can have either favorable or unfavorable effects, in accordance with the hypotheses of "pollution haven" or "pollution halo". Some believe that countries with lower environmental standards will attract more foreign investment and thus create a so-called "pollution haven" (Gray, 2002; Petrovic-Randjelović, 2007).

National investment policies can be implemented through different rules, laws, institutions and initiatives, while at the international level, the policy consists of a series of complex networks of agreements (investment agreements, trade agreements, etc.).

Incorporating the goal of sustainability in international investment agreements is certainly becoming a new trend. In order to be more successful in promoting and achieving sustainability the inclusion of new elements that support sustainable development in the agreements is necessary.

Finding financing sources for achieving sustainable development is not the only problem. Once the funds are collected, those need to be allocated towards wanted goals and sectors. Macroeconomic policy, industrial policy and overall development strategies of a country are factors that may affect investment in sectors related to sustainable development.

\section{European Union initiatives for financing sustainable development}

In recent decades, the need for sustainable development became a pressing issue on a global level. As the consensus on how to achieve development goals evolved, policies focused successively on poverty reduction, structural adjustments, and issues such as the environment, gender equality and empowerment of women and education for all. Development aid has played an integral part in this process, mostly because the least developed and developing countries are not able to achieve these goals on their own. Aid levels have therefore changed over time (European Commission, 2015a).

Through the adoption of the new global development agenda, the international community is called to respond in a transformative manner to fundamental challenges facing the world today (European Commission, 2015b). The Addis Ababa Action Agenda is a central part of the mentioned 2030 Agenda, which describes the means of implementation needed to achieve the targets of the SDGs. It is only by bringing together the means and the ends that the 2030 Agenda can be successfully implemented. An implementation must be driven by a new global partnership, one based on the principles of universality, shared responsibility, mutual accountability, consideration of respective capabilities and a multi-stakeholder approach (European Union, 2016).

The European Union (EU) and its members are committed to supporting this new global partnership and playing their part in full for the implementation of the agreed SDGs. Based on its values, the EU promotes democratic values and practices such as human rights, fundamental freedoms, good governance and the rule of law in both internal and external relations. Gender equality is an important element of the EU approach.

Providing over $50 \%$ of all global development aid, the EU is the world's leading aid donor (European Commission [online], 22.8.2016.). The EU can also offer its experience of implementing policies that reflect key principles of the 2030 Agenda such as sustainability, cooperation and partnerships. These range from the Europe 2020 Strategy, which aims to create smart, sustainable and inclusive growth through an integrated and coherent set of policy measures, to Policy Coherence for Development, and the Environment Action Programme (European Commission, 2015b). The European Union development policy can be seen as a cornerstone of the EU foreign relations. Made jointly by the three main EU institutions (Commission, Parliament and Council), the Consensus on Development identifies shared values, goals, principles and commitments which the European Commission and EU governments will implement in their development policies (European Commission [online], 22.8.2016):

- Reducing poverty,

- Democratic values: respect for human rights, democracy, fundamental freedoms and the rule of law, good governance, gender equality, solidarity and social justice, 
- Nationally-led development: by the beneficiary countries themselves, based on national strategies (developed in collaboration with non-government bodies) and domestic resources. Eu aid will be aligned with national strategies and procedures.

The EU places sustainable development as its fundamental and overarching goal. Economic, environmental and social dimensions are all part of the EU Sustainable Development Strategy (EU SDS) adopted in 2001 and renewed in 2006 (Eurostat, 2015). The overall aim of the renewed EU SDS is to identify and develop actions to enable the EU to achieve continuous improvement of quality of life, both for current and future generations through the creation of sustainable communities able to manage and use resources efficiently and to tap the ecological and social innovation potential of the economy, ensuring prosperity, environmental protection and social cohesion (Council of the European Union, 2006).

The context of adoption of the SDGs is an opportunity to consider internal EU activities relevant to this broad agenda, having regard to the EU SDS and the Europe 2020 strategy. The relationship between the EU SDS and the Lisbon Strategy, the predecessor of Europe 2020, was described as complementary. The EU SDS sets the overall framework, within which short- and medium-term strategies should operate, by providing a long-term perspective and clear and coherent guidance to all policy areas. Whereas the EU SDS is primarily concerned with quality of life, intra- and inter-generational equity and coherence between all policy areas, including international aspects, it recognizes the role of economic development in facilitating the transition to a more sustainable society (Eurostat, 2015). The measures of Europe 2020 should therefore be compatible with the long-term objectives of the EU SDS. In this sense, Europe 2020 can be seen as the practical implementation of the EU's overarching policy agenda for sustainable development.

Not only within the integration, but also on a global level, the EU is helping countries to mobilize more domestic resources, improve public finance management and ensure debt sustainability. There are several policy priorities that reflect EU's holistic approach to sustainable development finance and an integrated approach to key sectors of financing sustainable development.

As a signatory of the Addis Ababa Tax Initiative, the EU is investing EUR 42 million in a flagship programme of domestic resource mobilization to boost developing countries' generation of domestic revenue and tackle tax evasion, tax avoidance and illicit financial flows. The EU provides an average of EUR 140 million annually to support domestic public finance in developing countries (European Commission, 2015a).

Additionally, the EU has contributed, since 2000, EUR 1.6 billion in debt relief to least developed countries (LDCs), especially within the Highly Indebted Poor Countries Initiative (HIPC). Similarly, the European Investment Bank has contributed EUR 120 million in debt relief to LDCs (European Union, 2016).

As previously pointed out, private sector is a key partner in the development process, particularly with regard to job creation, as more than $90 \%$ of jobs in developing countries are within the private sector (European Commission, 2015a). The EU is leveraging more development funding through blending and seeking further partnerships with the private sector. From the creation of the first EU Facilities in 2007, more than EUR 2.7 billion of EU grants have leveraged almost EUR 23 billion of loans with a total investment volume in partner countries of more than EUR 50 billion In 2015, a new EU instrument, the African Investment Facility, was set up with an indicative pipeline of 148 projects. The Facility's total envisaged grant amount of around EUR 2 billion will contribute to projects having a total investment cost of more than EUR 25 billion (European Union, 2016).

The EU supports the development of competitive local private sectors, including by building local businesses and institutional capacity, promoting SMEs and cooperatives, supporting legislative and regulatory framework reforms and their enforcement, and facilitating access to business and financial services (European Commission, 2016). Through capacity-building and exchange of knowledge, the EU supports vocational training to enhance employability, productivity and competitiveness, especially among the young, who are more likely to be unemployed because of a lack of appropriate skills that match the demands of the current labor market. 
Furthermore, the EU collectively provides more official development aid than all other donors combined, having disbursed almost EUR 68 billion in 2015, an increase of $15 \%$ from 2014 (European Union, 2016). It has consistently supported developing countries with a range of actions, including the unilateral preferences afforded under the Generalized System of Preferences, bilateral and regional trade agreements, and the provision of aid for trade. Estimates indicate that their monetary value to the developing world amounts to more than EUR 6 billion annually. At the same time, they help to address social and other structural needs in partner countries. Collectively, the EU and its Member States remain - by a large margin - the most significant donor of aid for trade in the world, ahead of Japan (EUR 7.8 billion) and the United States (EUR 2.9 billion) (European Commission, 2015a).

While remittances have largely exceeded development assistance to developing countries, challenges remain to lower transaction costs and maximize development impact. Particular attention should be paid to reducing the cost of South-South remittances, which represent the largest share of remittances sent to the least-developed countries (European Commission, 2015a). At the Valletta EU-Africa Summit on Migration in November 2015, the EU and its Member States renewed their commitment to contribute to the reduction of remittance costs to below $3 \%$ by 2030 and to eliminate remittance corridors with costs higher than $5 \%$. The EU is supporting financial inclusion initiatives aimed at bringing 2 billion people into the formal financial system. This contributes to the effort to mobilize close to EUR 500 billion in global diaspora savings per year (European Union, 2016).

Another important area of sustainable development is climate change. The EU and its members are very actively engaged in addressing global climate change and have pioneered, collectively or individually, in creating new policies and innovative initiatives, such as the Global Climate Change Alliance and the National Appropriate Mitigation Actions programme to support efforts in this area (European Union, 2016). The EU has committed to spend at least $20 \%$ of its budget for 2014-2020 in action related to climate change. This means that, by 2020, at least EUR 14 billion of public grants will have supported activities in developing countries. In addition to funding managed by the European Commission, the European Investment Bank is one of the world's largest providers of climate finance. Almost $90 \%$ of the EUR 17 billion of sovereign climate finance pledges made in the run-up to the 2015 United Nations Climate Change Conference (COP21) came from the EU and its members (European Union, 2016).

Since 2007, the Global Climate Change Alliance between the EU and the partner countries most vulnerable to climate change has been supporting those vulnerable countries, in particular the Least Developed Countries and Small Island Developing States (SIDs) to increase their capacities to adapt to the effects of climate change. In addition, where it benefits their poverty reduction objectives, the Alliance is helping such countries to participate in the global climate change mitigation efforts (European Union, 2016).

In agriculture, the EU aims to support sustainable practices, including safeguarding ecosystem services, prioritizing locally developed practices and focusing on smallholder agriculture and rural livelihoods, the formation of producer groups, the supply and marketing chain, and government efforts to facilitate responsible private investment. The EU continues to work on strengthening nutritional standards, governance of food security and reducing food-price volatility at the international level (European Commission, 2016). By 2020, the EU will have invested EUR 8.8 billion in food and nutrition security, of which EUR 3.5 billion will help partner countries to reduce the number of children suffering from undernutrition by 7 million before 2025 (European Union, 2016).

On energy, the EU aims to offer technology and expertise focusing on three main challenges: price volatility and energy security; climate change, including access to low-carbon technologies; and access to secure, affordable, clean and sustainable energy services (European Commission, 2016). The EU is assisting developing countries in providing energy access for up to 500 million people by 2030. Through its support to the objectives of the Sustainable Energy for All initiative, the EU will allocate at least EUR 3.5 billion to the energy sector up to 2020. This should leverage around EUR 30 billion of energy investments in developing countries (European Union, 2016).

Science and technology are sectors of importance for supporting the sustainable development as well. The EU supports technology-related programmes involving developing countries through two major funding channels: 
the EU Framework Programme for Research and Innovation (Horizon 2020) and the development cooperation instruments managed by the Directorate-General for International Cooperation and Development (European Commission, 2015a). The EU's EUR 77 billion research and innovation programme, is fully open to participation from developing countries (European Union, 2016).

The EU committed considerable funds towards actions contributing to human development as it is an important component of aid policies. It supports the promotion and protection of civil and political rights as well as the promotion, protection and realization of economic, social and cultural right. The EU will have provided over EUR 7 billion in support of civil society, local authorities, democracy, the rule of law and human rights for the period up to 2020. Furthermore, it is estimated that by 2020, the EU will allocate at least $20 \%$ of its development budget (approximately EUR 3 billion per year) to human development, poverty eradication, health and safety, and social inclusion, with almost half of that allocated for health and a quarter for education (European Union, 2016). In fact, the EU is taking additional action to develop and strengthen health systems, reduce inequalities regarding access to health services, and increase protection against global health threats so as to improve health outcomes for all. A key policy area is enabling women to have access to skilled care during pregnancy and childbirth, to ensure prevention, detection and management of complications. Another policy priority is the immunization of young children under one year (European Commission, 2016).

\section{Conclusion}

Finding adequate sources of financing for sustainable development is as important as proper allocation of funds. Achieving the Sustainable Development Goals will foremost depend on successful development of national policies, their synergy and coherence. Public and private, domestic and international sources have an important role in financing development. While a certain level of government involvement is needed in terms of its strategic role and ensuring appropriate public funds, the existence of a healthy and stable economic and political system in the country is more important for attracting private investors. In the absence of necessary private or public funds countries depend on development aid. The EU is committed to supporting the new global partnership and the implementation of the latest global development agenda. Furthermore, the EU is a firm supporter of good global governance and is strongly committed to making aid more effective. In fact, aid effectiveness is an integral part of the broader financing for the development agenda. Although the EU committed to the new sustainable development agenda and has an important role as a leading global donor of development aid, in order to meet the expectations for development effectiveness regionally, it has to intensify its efforts and make more concrete actions, mainly in the area of division of labour, joint programming and transparency. This is necessary in order to change current development paths not only regionally, but on a global level as well.

\section{References}

Chandrasekhar, C. P. (2015). Potential and Prospects for Private Sector Contribution to Post-2015 Development Goals: How can Development Cooperation Strengthen Engagement and Results? Working Paper Series. Asian Development Bank.

Chudnovsky, D., Lopez, A. (2008). Foreign investment for sustainable development in Argentina. Discussion paper, No. 12. CENIT.

Council of the European Union (2006). Renewed EU sustainable development strategy. Brussels.

Dunning, J. (1993) Multinational Enterprises and the Global Economy. MA: Addison Wesley.

European Commission (2015a). 2015 EU Accountability Report on Financing for Development. Review of progress by the EU and its Member States. Brussels.

European Commission (2015b). Communication From The Commission To The European Parliament, The Council, The European Economic And Social Committee And The Committee Of The Regions: A Global Partnership for Poverty Eradication and Sustainable Development after 2015. Brussels.

European Commission (2016). EU International Cooperation and Development. First report on selected results, Results report. July 2013 - June 2014. Luxembourg: Publications Office of the European Union. 
European Commission. European consensus on development [online]. Retrieved from: http://ec.europa.eu/europeaid/policies/european-development-policy/european-consensus-development_en [22.8.2016]

European Commission. European development policy [online]. Retrieved from: http://ec.europa.eu/europeaid/policies/european-development-policy_en [22.8.2016]

European Union (2016). Financing Global Sustainable Development: Illustrations of EU contributions to the 2030 Agenda. Luxembourg: Publications Office of the European Union.

Eurostat (2015). Sustainable development in the European Union. 2015 monitoring report of the EU Sustainable Development Strategy. Luxembourg: Publications Office of the European Union.

Gray, K. R. (2002). Foreign direct investments and environmental impacts - Is the debate over? Oxford: Blackwell Publishing Ltd.

Moran, T. H. (1998) Foreign Direct Investment and Development, Washington: Institute for International Economics.

Petrovic-Randjelovic, M. (2007). Foreign Direct Investment and Sustainable Development: An Analysis of the Impact of Environmental Regulations on Investment Location Decisions. Facta Universitatis 4 (2).

Pirtea, M., Raisa Iovu, L., Miloš, M. C. (2008) Dynamics of financial markets in the context of globalization. Retrieved from: http://mpra.ub.uni-munchen.de/19889/ [20.10.2010.].

UNCTAD (2014). World Investment report. 2014: Investing in the SDG's. New York and Geneva: United Nations.

United Nations (2014). Report of the Intergovernmental Committee of Experts on Sustainable Development Financing. New York: United Nations.

Verghese, S. K. (1990). Financial innovation and lessons for India. Economic and political weekly, 25 (5): $265-272$. 